\title{
Effects of Steganotaenia Araliacae Root Extract on Contractile Function of Isolated Rat Ileum
}

\author{
Pharaoh Hamambulu' ${ }^{13 *}$ (D), Fastone Mathew Goma ${ }^{1}$ Kennedy Choongo $^{2}$, Newton Simfukwe ${ }^{1}$, Lukubi Lwiindi ${ }^{1}$ \\ Kwangu Chitembusha Mwenya ${ }^{3}$
}

\begin{abstract}
${ }^{1}$ Department of Physiological Sciences, School of Medicine, The University of Zambia, Lusaka, Zambia ${ }^{2}$ Department of Biomedical Sciences, School of Veterinary Medicine, University of Zambia, Lusaka, Zambia ${ }^{3}$ Department of Basic Medical Sciences, Michael Chilufya Sata, School of Medicine, Copperbelt University, Lusaka, Zambia
\end{abstract}

*Corresponding author: hamambulupharaoh@yahoo.co.uk

\section{Abstract}

To cite: Hamambulu P, Goma FM, Choongo K, Simfukwe N, Lwiindi L, Mwenya KC,. Effects of Steganotaenia Araliacae Root Extract on Contractile Function of Isolated Rat Ileum. JPRM 2021,3(2): 32-41. doi: 10.21617/jprm2021.328

Background: Various parts of a small tree, Steganotaenia araliacae are used as medicine in local traditional settings in Zambia to initiate and augment parturition although very little is documented about its physiological and pharmacological effects. Steganotaenia araliacae cold extract has been observed to cause contractions of uterus in rats but its effect on nonuterine muscle is unclear. The aim of this study was to establish the contractile effect of Steganotaenia araliacae cold extract on isolated rat ileum smooth muscle.

Method: Animals were sacrificed by cervical dislocation. Abdominal incisions were made to expose and dissect three ileum segments from each rat. The ileum segments were immediately transferred and mounted in the organ bath containing Tyrode solution. The contractile effects of acetylcholine (a reference agonist) and Steganotaenia araliacae cold extract on ileum segments were investigated starting with the least effective doses, thereafter doubling the doses until maximal tissue response was observed. Antagonists that include atropine, indomethacin, mepyramine, ondansetron and nifedipine in the presence and absence of Steganotaenia araliacae cold extract were also investigated to establish the mechanism of action Results: Steganotaenia araliacae cold extract increased the contractile force of isolated rat ileum in a dose-response manner but had no significant effects on the frequency of the spontaneous contractions. Pre-treating the tissue with atropine, indomethacin, mepyramine or ondansetron did not inhibit the contractile force of Steganotaenia araliacae cold extract, while pre-treating the tissue with nifedipine inhibited its contractile force by $100 \%(p<0.05)$

Conclusion: The cold root extract of Steganotaenia araliacae induced contractions on isolated rat ileum smooth muscle in a dose response manner by probable activation of calcium channels. It is possible that $\mathrm{SAE}^{\mathrm{c}}$ if used in high doses may cause severe abdominal cramps an effect that needs to be noted as it is being used in parturition.

Keywords: Rat ileum smooth muscle, Steganotaenia araliacae extract agonist, nifedipine antagonist 


\section{INTRODUCTION}

Steganotaenia araliacae (SAE), locally known as Fyopola (Chewa) is a small multipurpose savanna tree whose crude extract is one of the many herbal extracts traditionally used by local women in Zambia to induce and/or augment parturition [1]. Steganotania araliacae has also been used in management of various other ailments in in African folk medicine. Among the reported traditional uses of Steganotaenia araliacae extract include as snake venom antidote [2, 3, 4], treatment of fever and stomachache/dysentery [5] and treatment of Human immunodeficiency virus (HIV) infection [6]. A recent study by Ojerinde et al., revealed some antioxidant and antibacterial activity of SAE [7]. Two other studies one by Matowa et al., and the other by Abdurahman et al., has revealed anticancer and antidiuretic activity [8,9] of SAE respectively. These findings justify the traditional uses of the extract of SAE in management of some medical conditions in folk medicine. Phytochemical screening of the menthol extract of the seeds of SAE by Mussie et al., and another study by Meragelman revealed presence of many bioactive metabolites one of which showed antiproliferative activity against ovarian cancer $[10,11]$. Presence of some bioactive compounds in the crude extract of SAE justifies another reason for its traditional use and calls for further experimental research on it which may lead to the discovery of a new drug for use in conventional medicine.

Most herbal medicines are used as crude extracts and may have multiple adverse effects on the function of body systems. Steganotaenia araliacae water extract has been shown to increase contractility of isolated rat uterine smooth muscle in a dose - response manner [12], but its effects on the function of the gastrointestinal system and several other organ systems is still not clear. More studies need to be done to investigate the effects of this plant both in vitro and in vivo to reveal possible clinical implications of its use and its toxicity.

Smooth muscle is a major component of the uterus and ileum so there are several similarities in regulation of their contractile process. We therefore found it imperative to investigate the effects of Steganotaenia araliacae extract on ileum smooth muscle function. This study will enable the users of SAE either to facilitate labor or indeed for several other traditional uses to be well informed of its effects on gastrointestinal function. Any substance that Interferes with the normal contractile process of gastrointestinal smooth muscle would result in gastrointestinal disturbances e.g. diarrhea, abdominal cramps, constipation, nutrient indigestion and nutrient malabsorption. The aim of this study was to establish the effects of Steganotaenia araliacae extract on the contractile function of isolated rat ileum.

\section{METHODS AND MATERIALS Plant materials}

Fresh plants with leaves and roots of $S$. araliacea were collected from traditional birth attendants and some other knowledgeable local people in Chongwe townships of Lusaka province of Zambia. Identification and authentication of the plant was done at The University of Zambia (UNZA), School of Natural Sciences, in the herbarium section where the sample was assigned voucher number of LL2. Fresh root barks of $S$. araliacea were collected and washed to remove adulterants and soil particles. The barks were chopped into bits and dried in the shade for 14 days. The dried root barks were further reduced to powder by pounding in mortar with pestle. $362.67 \mathrm{~g}$ quantity of powder was weighed using an electronic balance (Model: BPS-1000- $\mathrm{C}_{2}-\mathrm{V}_{2}$, Serial No. : 453040/15, Manufacturer: MRC. Ltd) and soaked in $1800 \mathrm{ml}$ of distilled water for 24 hours. The mixture was sieved and squeezed through a mutton cloth to get rid of large particles. The infusion was then centrifuged at 2000 rpmfor 10 minute using a centrifuge (MFG No.:99698, CAT No.: 001472, Manufacturer: Hitachi koki co.Ltd). The supernatant was decanted and filtered using Whitman filter paper size No.1 to obtain a brown filtrate. The filtrate was concentrated to a volume of about $400 \mathrm{ml}$ using a laboratory hot plate (Model No: 13474, Manufacturere: Ikemoto Rikakogyo co.Ltd) and later in a hot air drying oven (Model: DG-81, Manufacturer: Yamato co. Ltd, Japan) at $60^{\circ} \mathrm{C}$ to complete dryness until a constant weight of a brown semi-solid extract was obtained which was named Steganotaenia araliacea cold water extract $\left(\mathrm{SAE}^{\mathrm{c}}\right)$.

\section{Animals}

Eight (8) female gravid albino rats of Wistar strain (Rottus norvegicus) weighing 180 250 grams were selected and housed in the animal unit of the Department of Biomedical sciences, School of Medicine, University of Zambia for a period of two weeks. The animals were maintained according to standard nutritional and 
environmental conditions, had free access to standard feed (Bendel Feeds and Flour Mill) and water. Animal studies were conducted according to standard guidelines for use of laboratory animals [13].

Drugs

Acetylcholine $\left(1.65 \times 10^{-3} \mathrm{M}\right)$ was used as reference agonist drug with atropine sulphate $(6 \mathrm{x}$ $\left.10^{-2} \mu \mathrm{g} / \mathrm{ml}\right)$ as its antagonist. Nifedipine (2.9 $\left.\mathrm{x} 10^{-4} \mathrm{M}\right), \quad$ Indomethacine $\quad(1.2 \mathrm{mg} / \mathrm{ml})$, mepyramine $(100 \mu \mathrm{g} / \mathrm{ml})$ and ondasentron $(136$ $\mathrm{mM}$ ) were used as antagonists to investigate the mechanism of action of Steganoteania araliacea extract.

\section{Extraction and mounting of the isolated rat ileum}

Animals were humanely sacrificed by a quick cervical dislocation. An abdominal incision was made to expose the visceral organs and the ileum was identified. The ileum was dissected out and transferred into a beaker containing Tyrode solution at $37^{\circ} \mathrm{C}$. Intestinal contents were removed by flushing with Tyrode solution and the ileum from each rat was cut into 3 segments of 2 $-3 \mathrm{~cm}$ long. A thread was attached to one end of the isolated ileal segment and fixed to a lever system fitted on the isometric transducer (Make: MLT 0210/A, Serial No.: 1003011, Manufacturer: Panlab, S.L, Spain) and the other end was fixed to a hook. The tissue was transferred and mounted in a $25 \mathrm{ml}$ organ bath containing Tyrode solution maintained at $37^{\circ} \mathrm{C}$ and aerated with ordinary air with Sonic aquarium air pump (Model No: 9905). An initial resting tension of $1 \mathrm{~g}(10 \mathrm{mN})$ was applied to the mounted segments. The tissues were left to stabilize in the organ bath for 60 minutes before any drug was administered while the physiological solution was replaced with fresh one every 15 minutes

\section{Experimental design}

The effects of none-cumulative concentrations of acetylcholine $\left(1.817 \times 10^{-6}\right.$ $\left.\mathrm{mg} / \mathrm{ml}-1.817 \times 10^{-3} \mathrm{mg} / \mathrm{ml}\right)$ and $\mathrm{SAE}^{\mathrm{c}}(1 \mathrm{mg} / \mathrm{ml}$ - $40 \mathrm{mg} / \mathrm{ml}$ ) on contractile response of the mounted isolated ileum were investigated to obtain dose-response curves. In another experiment the contractile effects of $\mathrm{SAE}^{\mathrm{c}}$ $(8 \mathrm{mg} / \mathrm{ml})$ and acetylcholine $\left(5 \times 10^{-5} \mathrm{mg} / \mathrm{ml}\right)$ in the presence of atropine $\left(4.8 \mathrm{mg} \times 10^{-4} \mathrm{mg} / \mathrm{ml}\right)$, indomethacin $\quad(0.036 \mathrm{mg} / \mathrm{ml}), \quad$ nifedipine $\left(2.9 \times 10^{-4} \mathrm{M}\right)$, mepyramine $(1 \mu \mathrm{g} / \mathrm{ml})$ or Ondansetron $(1 \mu \mathrm{M})$ were investigated in an attempt to establish the probable mechanism of action of $\mathrm{SAE}^{\mathrm{c}}$. After each drug or extract administration, the tissue was washed three times with fresh physiological salt solution and allowed appropriate time to recover (return to baseline) before subsequent additions of drugs or extract. The contractile response of the isolated ileum to each treatment was recorded using the ML856 PowerLab 26T (Model: ML 856, Manufacturer:Panlab, S. L, Spain) and recorded on a graph displayed by LabTutor.

\section{Statistical analysis}

All values were expressed as the mean \pm SEM (standard error of the mean) and ' $n$ ' represents the number of rats from which ileum segments were obtained. GraphPad Prism version 5 statistical package was used for statistical analysis. The levels of significance were made using one-way ANOVA with Bonferroni's Multiple Comparison Test for comparison of means between groups. A value of $\mathrm{P}<0.05$ was considered significant in all cases.

\section{RESULTS}

The objectives of the study were to measure the change in isometric tension and contractile frequency of isolated rat ileum produced by cold extract of $\mathrm{SAE}^{\mathrm{c}}$, and determines its possible mechanism of action. Various noncumulative concentrations of cold-water root extract of $\mathrm{SAE}^{\mathrm{c}}$ were administered in the organ bath where segments of isolated rat ileum were mounted each at a time. Doubling the dose of $\mathrm{SAE}^{\mathrm{c}}$ increased the contractility (tension) and showed a dose-response relationship as indicated below (Figure 1, a), b), c), d), e), f), g) and Table 1) of isolated ileum. Increase in concentration of $\mathrm{SAE}^{\mathrm{c}}$ form $1 \mathrm{mg} / \mathrm{ml}$ to $32 \mathrm{mg} / \mathrm{ml}$ resulted in a proportional increase in tissue response. However, doses of $\mathrm{SAE}^{\mathrm{c}}$ higher than $32 \mathrm{mg} / \mathrm{ml}$ did not result in any further increase in tissue response (Table 1) implying that all the available receptors for $\mathrm{SAE}^{\mathrm{c}}$ were saturated at $32 \mathrm{mg} / \mathrm{ml}$.

A plot of Log-dose of $\mathrm{SAE}^{\mathrm{c}}$ and Ach against maximal tissue response showed a doseresponse relationship. The curves were sigmoidal in shape, typical of drug-receptor interaction as illustrated in Figure 2. The curves also showed that Ach was more potent than $\mathrm{SAE}^{\mathrm{c}}$.

The mechanism of action of $\mathrm{SAE}^{\mathrm{c}}$ involved direct or indirect opening of calcium channels because pretreating the tissues with nifedipine inhibited the contractions caused by both acetylcholine and $\mathrm{SAE}^{\mathrm{c}}$ by $100 \%(\mathrm{p}<0.05)$ from $11.642 \mathrm{mN}$ to $0 \mathrm{mN}$ for acetylcholine and from $13.652 \mathrm{mN}$ to $0 \mathrm{mN}$ for $\mathrm{SAE}^{\mathrm{c}}$ (Figure 3). Pretreating the tissues with indomethacin, ondansetron $(1 \mu \mathrm{M})$, and mepyramine $(1 \mu \mathrm{g} / \mathrm{ml})$ did not inhibit the contractions caused by either 
acetylcholine or $\operatorname{SAE}^{c}(p>0.05)$. This indicated none involvement of prostaglandine, (serotonergic) $5-\mathrm{HT}_{3}$ and (histaminergic) $\mathrm{H}_{1}$ receptors in the contractile response produced by Ach and $\mathrm{SAE}^{\mathrm{c}}$ respectively (Figure 4, 5 and 6). Atropine physiologically inhibited the ileum contractions produced by acetylcholine by about $55 \%(\mathrm{p}<0.05)$ from average of $11.642 \mathrm{mN}$ to $5.264 \mathrm{mN}$. The same dose of atropine did no inhibit the contractions caused by $\operatorname{SAE}^{c}(p>0.05)$

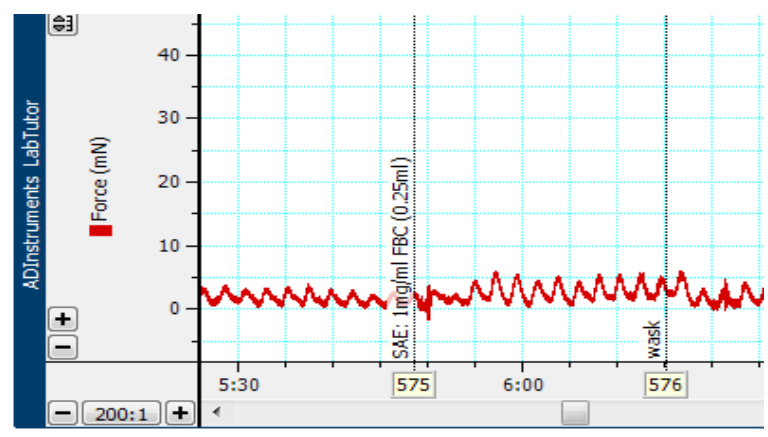

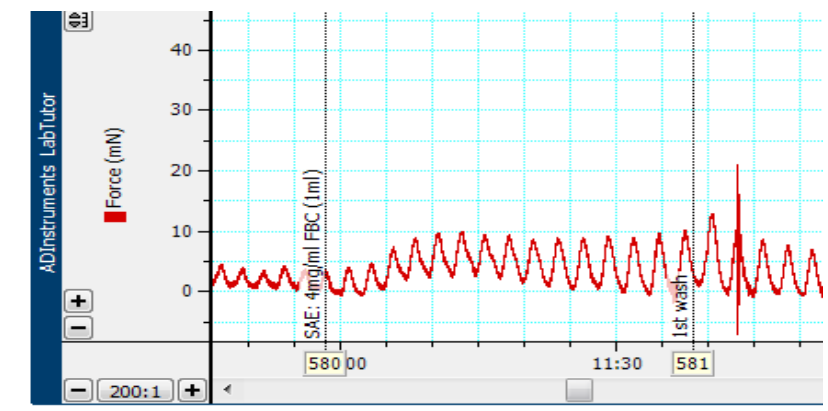

c) $\mathrm{SAE}^{\mathrm{c}}$ at $4 \mathrm{mg} / \mathrm{ml}$

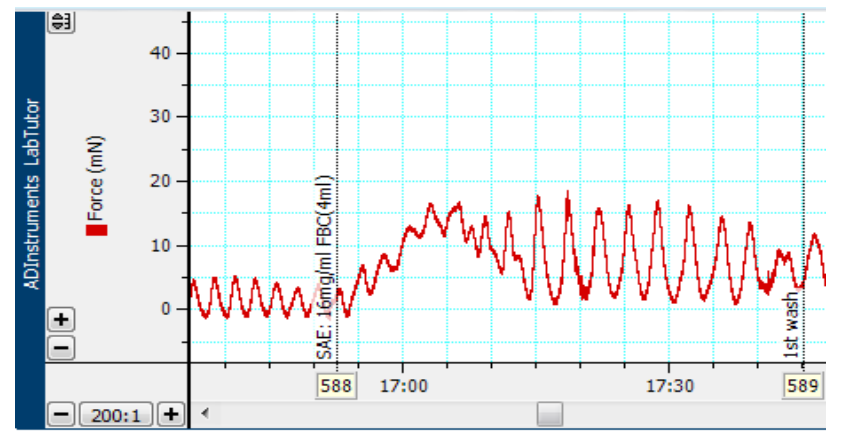

e) $\mathrm{SAE}^{\mathrm{c}}$ at $16 \mathrm{mg} / \mathrm{ml}$ (figure 7) indicating none involvement of muscarinic receptors $\left(\mathrm{M}_{3}\right)$ in contractile pathway produced by $\mathrm{SAE}^{\mathrm{c}}$.

\section{Effects of $S A E^{c}$ on contractility and frequency of spontaneous contractions}

Administration of various non-cumulative concentration of $\mathrm{SAE}^{\mathrm{c}}$ increased the contractility (tension) (Fig.1, a), b), c), d), e), f), g) and Table 1) of isolated ileum

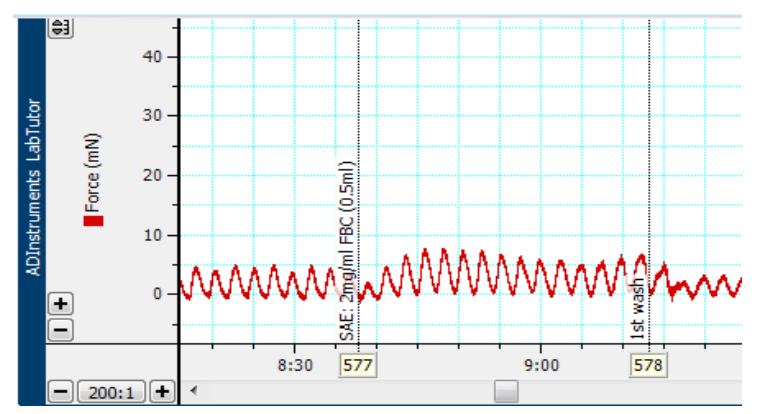

b) $\mathrm{SAE}^{\mathrm{c}}$ at $2 \mathrm{mg} / \mathrm{ml}$

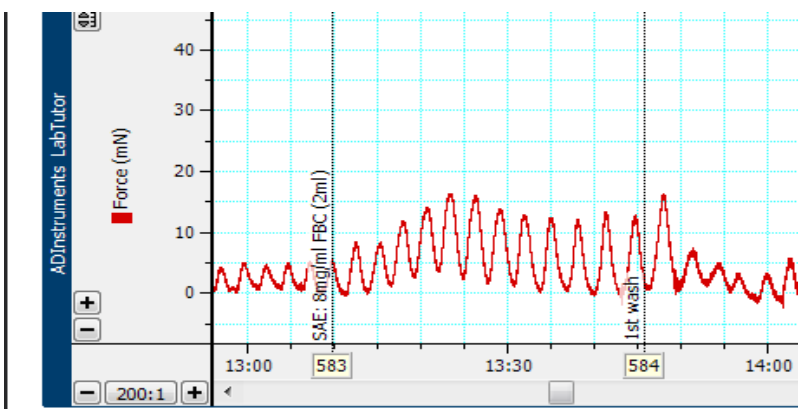

d) $\mathrm{SAE}^{\mathrm{c}}$ at $8 \mathrm{mg} / \mathrm{ml}$

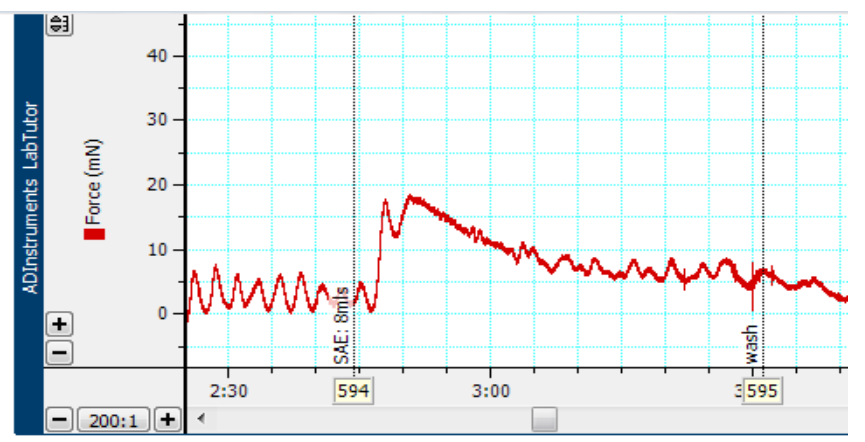

f) $\mathrm{SAE}^{\mathrm{c}}$ at $32 \mathrm{mg} / \mathrm{ml}$

Figure 1: Tracing showing tissue response (tension) of rat ileum muscle following administration of various doses of $S A E^{c}$ 
Table 1: Effects of non-cumulative $S A E^{c}(100 \mathrm{mg} / \mathrm{ml})$ concentration on amplitude and frequency of spontaneous contractions of the ileum $(n=3)$

\begin{tabular}{|c|c|c|}
\hline $\begin{array}{l}\text { Bath concentration } \\
\text { of SAE }(\mathrm{mg} / \mathrm{ml})\end{array}$ & $\begin{array}{l}\text { Frequency } \\
\text { contractions } \\
\text { (per minute) }\end{array}$ & $\begin{array}{l}\text { Amplitude } \\
(\mathrm{mN})\end{array}$ \\
\hline 1 & 19 & 7.43 \\
\hline 2 & 18 & 8.90 \\
\hline 4 & 20 & 10.47 \\
\hline 8 & 17 & 15.63 \\
\hline 16 & 18 & 17.13 \\
\hline 32 & - & 19.81 \\
\hline 64 & - & 19.21 \\
\hline
\end{tabular}

Ach and SAE dose response curves

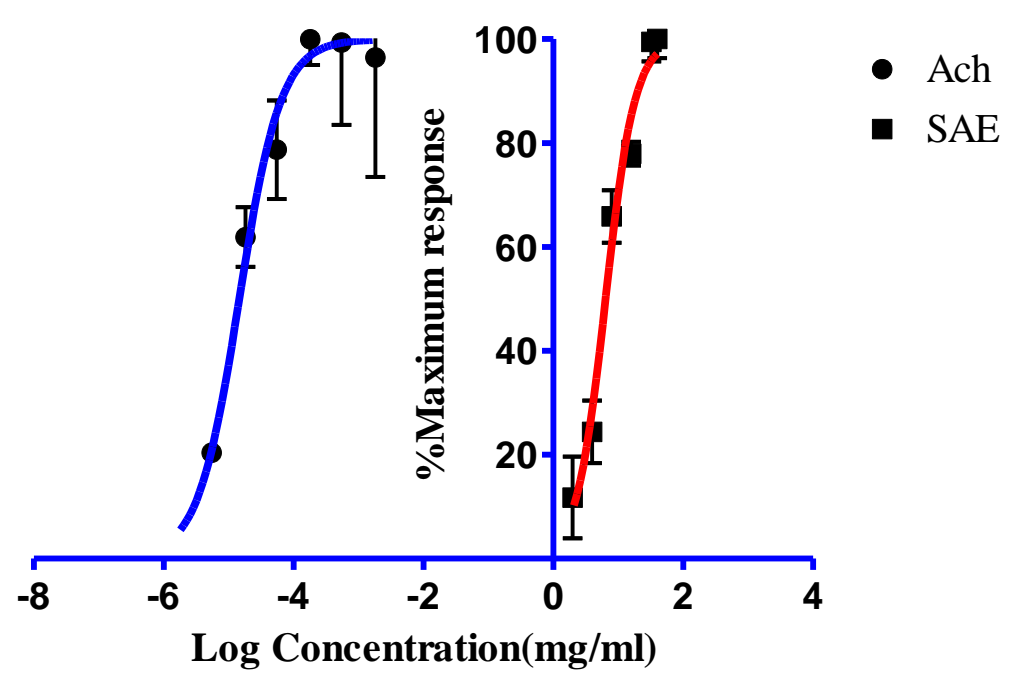

Figure 2: Log dose-response curves of acetylcholine $\left(1.817 \times 10^{-6} \mathrm{mg} / \mathrm{ml}-1.817 \times 10^{-3} \mathrm{mg} / \mathrm{ml}\right)$ and $\mathrm{SAE}^{\mathrm{c}}$ $(1 \mathrm{mg} / \mathrm{ml}-40 \mathrm{mg} / \mathrm{ml})$ on isolated rat ileum. Each point is the mean $\pm \operatorname{sem}(\mathrm{n}=3)$ 


\section{Determination of the mechanism of action of $S A E^{\mathrm{c}}$}

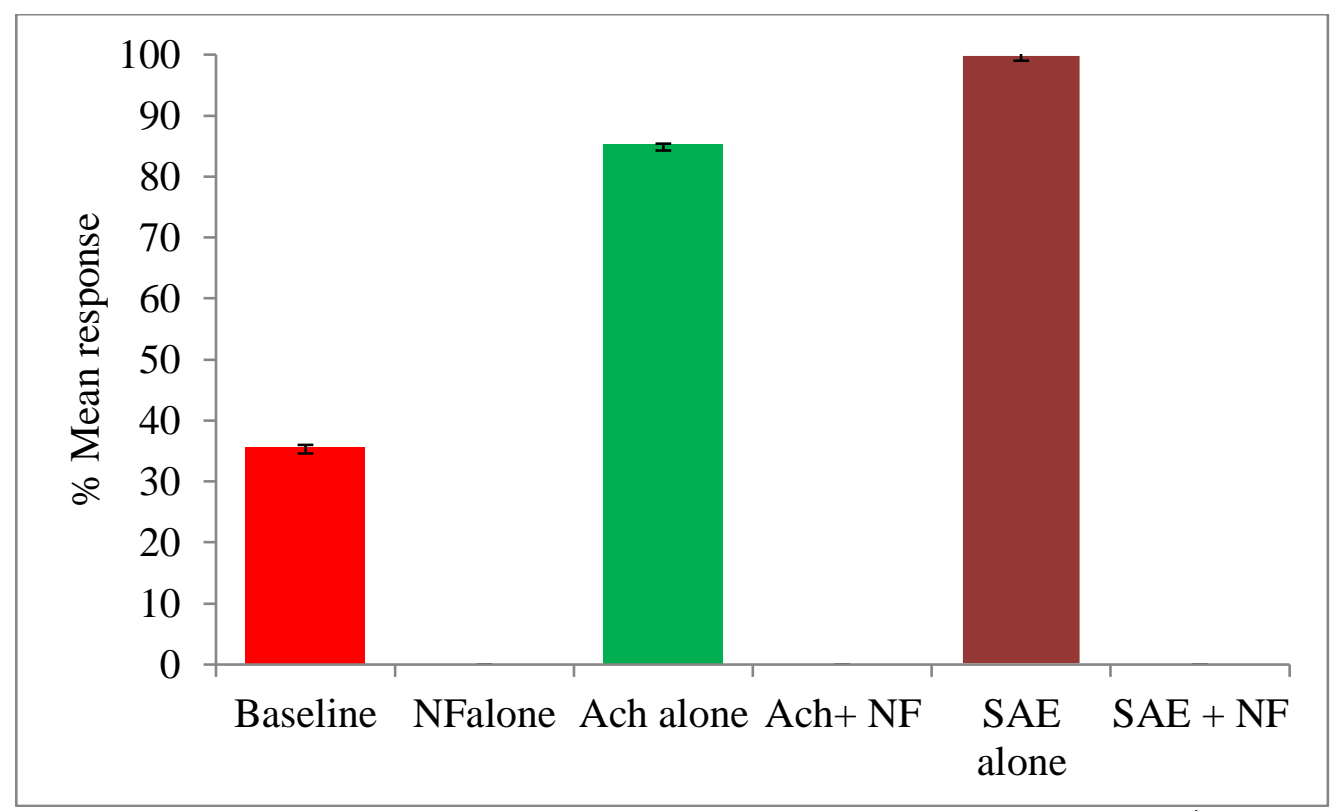

Figure 3: Effects of nifedipine $\left(2.9 \times 10^{-4} \mathrm{M}\right)$ on responses produced by Ach $\left(5 \times 10^{-5} \mathrm{mg} / \mathrm{ml}\right.$ and $S A E^{c}$ $(8 \mathrm{mg} / \mathrm{ml})$ on isolated rat ileum. Each column represents the mean \pm sem $(n=3$ rats)

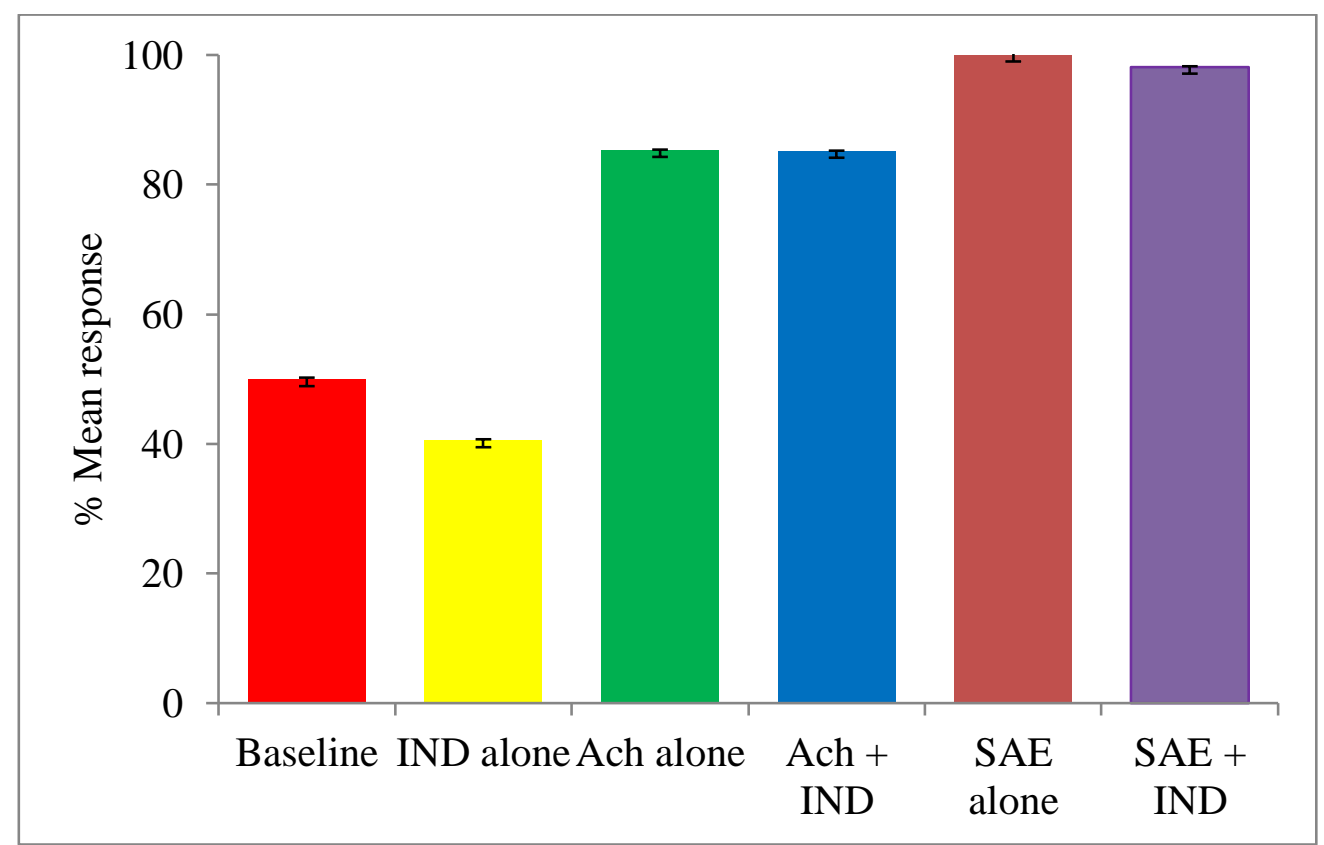

Figure 4: Effects of indomethacin $(0.036 \mathrm{mg} / \mathrm{ml})$ on responses produced by acetylcholine $\left(5 \times 10^{-5} \mathrm{mg} / \mathrm{ml}\right.$ and $S A E(16 \mathrm{mg} / \mathrm{ml})$. Each column represents the mean $\pm \operatorname{sem}(n=3$ rats). 


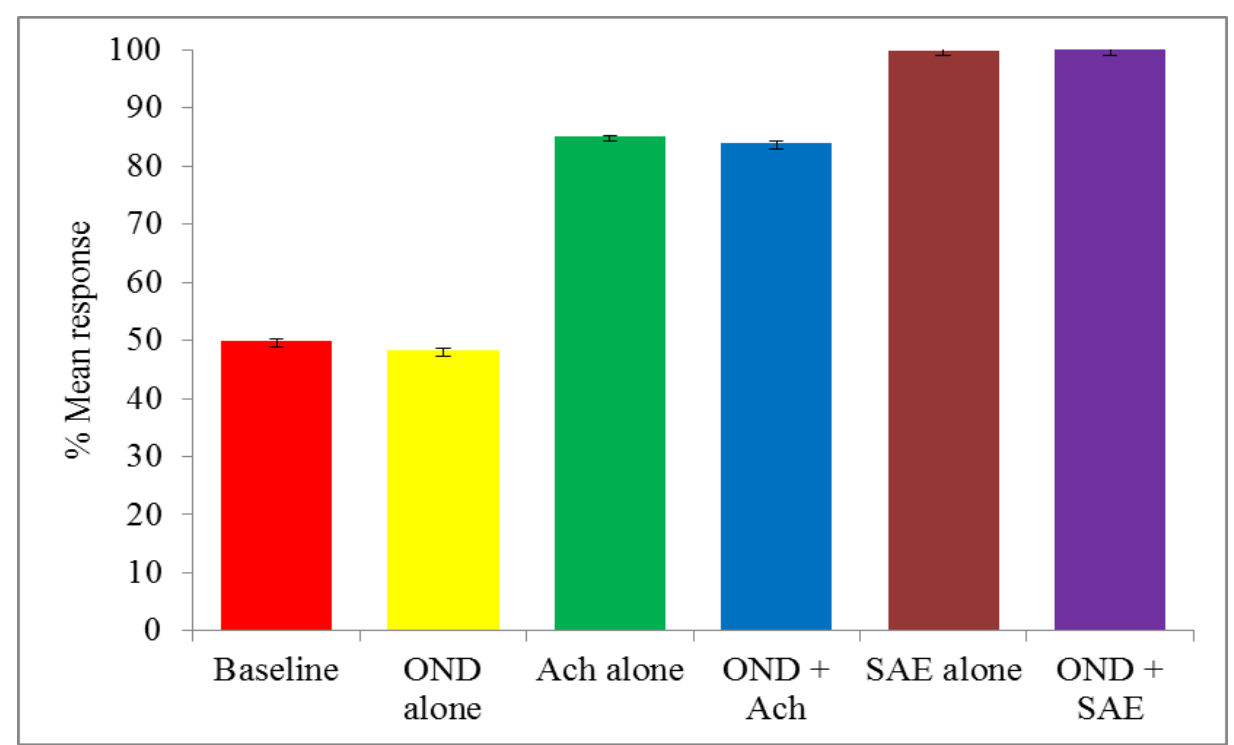

Figure 5: Effects of Ondansetron (1 $\mu M)$ on responses produced by $\mathrm{Ach}\left(5 \times 10^{-5} \mathrm{mg} / \mathrm{ml}\right.$ and SAE $(8 \mathrm{mg} / \mathrm{ml})$ on isolated rat ileum. Each column represents the mean $\pm \operatorname{sem}(n=3$ rats).

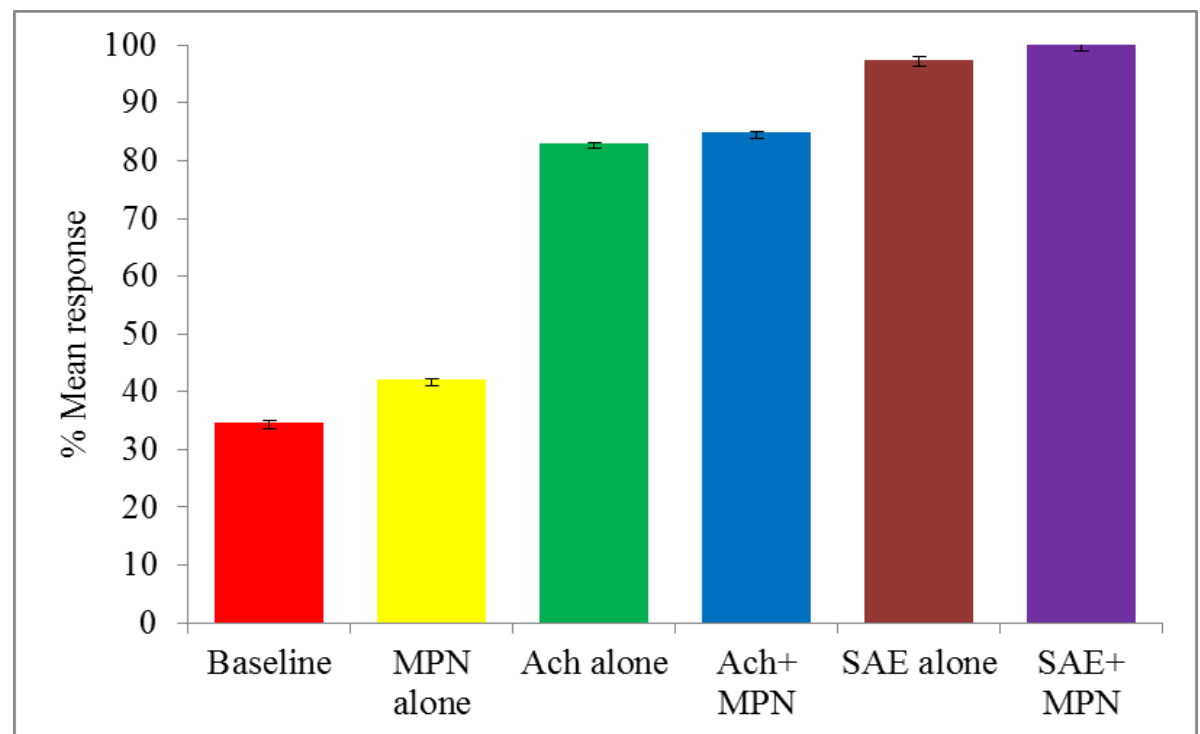

Figure 6: Effects of mepyramine $(1 \mu \mathrm{g} / \mathrm{ml})$ on responses produced by Ach $\left(5 \times 10^{-5} \mathrm{mg} / \mathrm{ml}\right.$ and $S A E$ $(8 \mathrm{mg} / \mathrm{ml})$ on isolated rat ileum. Each column represents the mean $\pm \mathrm{sem}(\mathrm{n}=3 \mathrm{rats})$. 


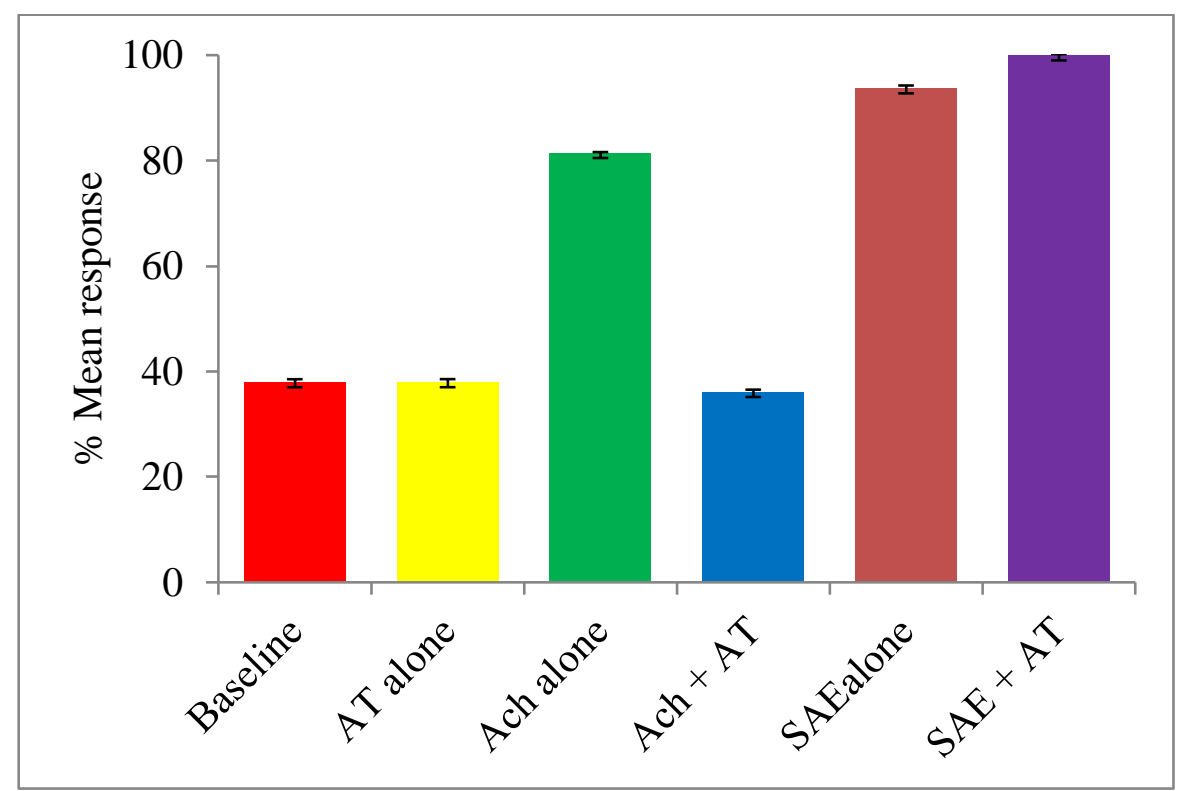

Figure 7: Effect of Ach $\left(5 \times 10^{-5} \mathrm{mg} / \mathrm{ml}\right.$ and $S A E^{c}(8 \mathrm{mg} / \mathrm{ml})$ in presence of atropine $\left(4.8 \mathrm{mg} \times 10^{-4} \mathrm{mg} / \mathrm{ml}\right)$ on the isolated rat ileum. Each column represents the mean \pm sem $(n=3$ rats).

\section{DISCUSSION}

The study set out to determine the contractile effects of $\mathrm{SAE}^{\mathrm{c}}$ on isolated rat ileum. A sample of 24 rat ileum segments were harvested from 8 gravid female rats $(3$ segments from each rat) and selected for this study. Our findings showed that $\mathrm{SAE}^{\mathrm{c}}(1 \mathrm{mg} / \mathrm{ml}-64 \mathrm{mg} / \mathrm{ml})$ increased contractile force of rat ileum smooth muscle in a dose-response manner, but the same doses had no significant effect on frequency of spontaneous contractions. This observation opposed the findings of a previous study by Alemeka et al., where ethanol extract of SAE caused relaxation of rabbit jejunum. In the study by Alemeka et al., lower doses of $\operatorname{SAE}^{c}(0.1 \mathrm{mg} / \mathrm{ml}$ to $3.2 \mathrm{mg} / \mathrm{ml})$ caused relaxation and reduced motility of isolated rabbit jejunum in a dose-response manner [14]. The discrepancy between our study and the study by Alemeka cited above could be due to differences in the extraction solvents and methods, dosage and experimental animal species used. Another study by Goma et al., revealed that $\mathrm{SAE}^{\mathrm{c}}$ increase contractility and motility of rat uterus smooth muscle in a dose response manner but at much lower doses $(0.016 \mathrm{mg} / \mathrm{ml}-2.048 \mathrm{mg} / \mathrm{ml})$ indicating that the uterus is much more sensitive to $\mathrm{SAE}^{\mathrm{c}}$ than the ileum [15]. The observed difference in potency of SAE between our study and that done by Goma et al., could be that SAE activates different contraction pathways in the rat uterus compared to the ileum. It may also justify the absence of gastrointestinal associated complaints in women who take the herb.

A few studies on the toxicity of the extract of SAE have been done. In an acute toxicity study by Ezeala et al., very high oral doses of $10,000 \mathrm{mg} / \mathrm{kg}$ did not cause death or significant damage to liver, pancreas, heart and kidneys in Wister rats indicating high safety when orally administered [16]. However, a study by Agunu et al., revealed the unsuitability of methanolic extract of SAE stem-bark for human therapy because significant liver, intestinal and kidney damage caused death of $50 \%$ of male rats at intraperitoneal dose of $1.75 \mathrm{~g} / \mathrm{kg}(\operatorname{LD} 50)$ [17]. The opposing findings by these two studies could be attributed to route of administration and the method of extraction of the SAE. Oral route of administration may have reduced the bioavailability of the extract to vital organs due to its enterohepatic circulation and metabolism by liver and gastrointestinal tract. This could reduce the dose from reaching toxic levels in the liver, kidney, pancreas and intestines compared to higher dose that could be obtained if the extract was given by intraperitoneal route. The extraction method used by Agunu et al., involved use of methanol. The use of methanol for extraction could have increased the number and types of metabolites extracted from the plant some of which may have been involved in acute toxicity that was observed. In contrast, the extraction method used by Ezeala et al., involved cold water that could have failed to dissolve toxic plant 
metabolites hence no acute toxicity observed. These results signify that the cold extract of SEA is relatively safe when orally taken and at lower doses effective for inducing uterine contractions to facilitate labor but calls for caution at higher doses. More toxicity and potency studies in live female gravid rats are supposed to be done to further determine its safety.

Physiological pathways controlling smooth muscle contraction involve increasing intracellular calcium concentration. Calcium entry into smooth muscle cells may be through any or a combination of all of the following ways; voltage-gated calcium channels in response to cell depolarization, calcium release from sarcoplasmic reticulum or entry of calcium from voltage independent channels [18]. These calcium channels could be opened by stimulation of one or several receptors that include histaminergic $\left(\mathrm{H}_{1}\right)$ receptors [19], serotonergic $\left(5-\mathrm{HT}_{3}\right)$ receptors [20], muscarinic $\left(\mathrm{M}_{2}\right.$ and $\left.\mathrm{M}_{3}\right)$ receptors [21] and activation of L-type calcium channels by depolarization of the plasma membrane [22]. The observed increased contractility of rat ileum smooth muscle caused by $\mathrm{SAE}^{\mathrm{c}}$ could be through activation of one or more of the pathways involved in ileum smooth muscle contraction. One of the aims of our study was to find the probable mechanism by which $\mathrm{SAE}^{c}$ caused the observed dose-response effect on contractility of isolated rat ileum smooth muscle. This was done by pretreating the tissue with atropine $\left(\mathrm{M}_{1}\right.$ and $\left.\mathrm{M}_{2}\right)$ receptor antagonist [23], nifedipine, calcium channel blocker [24], indomethacin (prostaglandin synthetase inhibitor [25], mepramine, an $\mathrm{H}_{1}$ receptor antagonist [26] and ondansetron, an $5-\mathrm{HT}_{3}$ antagonist. The ileum contractions caused by $\mathrm{SAE}^{\mathrm{c}}$ were not inhibited by atropine, indomethacin, ondansetron or mepyramine. However, pretreating the tissue with nifedipine inhibited the isolated ileal contractions caused by $\mathrm{SAE}^{\mathrm{c}}$ by $100 \%$. This observation suggested that $\mathrm{SAE}^{\mathrm{c}}$ probably stimulated the ileum contractions through calcium channels activation by either acting directly or indirect.

\section{CONCLUSION}

It can be concluded that $\mathrm{SAE}^{\mathrm{c}}$ causes contractions of isolated rat ileum smooth muscle in a dose-response manner. The mechanism of action may be by probable activation of calcium channels. From our observations and the review of some previous studies, it is worth noting that herbal medicines may have multiple effects on function of body systems depending on the dose and toxicity of the herbal extract. It is possible that $\mathrm{SAE}^{c}$ if used in high doses could cause severe abdominal cramps which may be controlled by nifedipine. Further works need to be done to investigate short- and long-term effects of $\mathrm{SAE}^{\mathrm{c}}$ on functions of all body systems.

\section{DECLARATION}

Acknowledgement The authors are grateful to The University of Zambia, School of Medicine specifically the Physiological Sciences technical staff for their tireless support towards data acquisition for this work

\section{Funding None}

Competing interests There were no competing interests from all authors in this study.

\section{REFERENCES}

1. Sylvia Maluma, Chichonyi A. Kalungia, Audrey Hamachila, Jimmy Hangoma, Derick Munkombwe. Prevalence of Traditional Herbal Medicine use and associated factors among pregnant women of Lusaka Province, Zambia. Journal of Preventive and Rehabilitative Medicine. 2017; 1(1): 5-11.

2. Payel Bhattacharjee and Debasish Bhattacharyya. Medicinal plants as snake venom antidotes. Journal of Experimental and Applied Animal Sciences. 2013; 1(1): 156-181.

3. Z. Emmanuel Selvanayagam, S. G. Gnanavendhan, K. Balakrishna and R. Bhima Rao. Antisnake Venom Botanicals from Ethnomedicine. 2010 ;Journal of Herbs Spices \& Medicinal Plants 2 (4):45-100.

4. Bethwell O Owuor and Daniel P Kisanga. Kenyan medicinal plants used as antivenin: a comparison of plant usage. Journal of Ethnobiology and Ethnomedicine 2006. 2:7

5. Orwa C, Mutua A, Kindt R, Jamnadass R, Simons A. 2009. Agroforestree Database:a tree reference and selection guide version 4.0. (http://www.worldagroforestry. Org/af/treedb/)

6. Omolo J.J, Maharaj V, Naidoo D, Malebo H.M, Mtullu S, Lyaruu H.V.M, de Koning, C.B. Flavonoids of Steganotaenia araliacea. American Journal of Research Communication. 2014. 2(8)

7. Stephen O. Ojerinde, Babajide A. Adepoju, James J. Edache, Efosa M. Okundaye and Taiwo E. Alemika. Antioxidant and antibacterial constituents of Steganotaenia araliacea stem bark. J. Pharmacy and Bioresources. 2013. 10(1): 25-32

8. Patrick R Matowa, Felistus Chando, Charles F.B Nhachi

Mazuru Gundidza. Evaluation of anticancer activity of Steganotaenia araliacea (carrot tree) bark extract in cancer induced mammary glands of female sprague dawley rats. International 
Journal of Humanities, Arts, Medicine and Sciences. 2019. 7(1); 7-16

9. E.M.Abdurahman, G.O.Andrew and Z.Muhammed. Diuretic activity of the stem-bark extracts of Steganotaenia araliacea hochst [Apiaceae]. Journal of Ethnopharmacology.2004. 96(3)

10. Demoz, M.S., Gachoki, K.P., Mungai, K.J. and Negusse, B.G. GC-MS Analysis of the Essential Oil and Methanol Extract of the Seeds of Steganotaenia araliacea Hochst. 2014. American Journal of Plant Sciences, 5, 3752-3760

11. Karina M. Meragelman, Tawnya C. McKee and Michael R. Boyd. 10 Demethoxystegane, a New Lignan from Steganotaenia araliacea. J. Nat. Prod. 2001, 64, 11, 1480-1482

12. Lwiindi L, Goma F, Mushabati F, Prashar L, Choongo K. Physiological response of uterine muscle to Steganoteania araliacea in rat models. Jour of Med Sc \& Tech. 2015; 4(1) : 40 - 45.

13. Sciences CfIOoM. International guiding principles for biomedical research involving animals: World Health Organization; 1985

14. Alemika T.E, Onawunmi G. O and Olugbade T. A. (September 2004). Protocatechuic acid and saponin mixture from Steganotaenia araliacea stem bark. Nigerian Journal of Pharmaceutical Research. 2004; 3 (1): 9-15.

15. F M Goma, C Ezeala, J Nyirenda, L Prashar, N Simfukwe, C Lengwe. Extraction and Demonstration of Uterotonic Activity from the Root of Steganotaenia Aralicea Hochst.Medical Journal of Zambia. 2017; 44 (3): 125 - 132

16. Ezeala, Christian, Goma Fastone, Nyirenda James, Prashar Lavina, Simfukwe Newton and Lengwe Chilufya. Biochemical Evaluation of the Safety of Steganotaenia araliacea Hochst (Apiaceae) Root Extract in Rodents. 2018. ScholarOne, 375 Greenbrier Drive, Charlottesville, VA, 22901

17. A Agunu, N.D.G Ibrahim, G.A Onyiloyi and E.M Abdurahman. Toxicity of stem-bark extract of Steganotaenia araliacea in rats. Nigerian Journal of Natural Products and Medicine. 2004. 7(1)

18. Boron WF and Boulppaep EL. Medical Physiology $3^{\text {rd }}$ edition. 2012. Saunders Elsevier Inc

19. Izzo A. A, Costa M, Mascolo N and Capasso F. (June 24, 1998). The Role of Histamine $\mathrm{H}_{1}, \mathrm{H}_{2}$ and $\mathrm{H}_{3}$ Receptors on Enteric Ascending Synaptic Transmission in the Guinea Pig Ileum. The Journal of Pharmacology and Experimental Therapeutics.1998; 287(3): 952-957.

20. Thompson A. J and Lummis S.C.R. 5-HT3 Receptors. Curr Pharm Des. 2006; 12(28): 3615-3630.
21. William T. Gerthoffer W. T. Signal-Transduction Pathways that Regulate Visceral Smooth Muscle Function III. Coupling of muscarinic receptors to signaling kinases and effector proteins in gastrointestinal smooth muscles. Am J Physiol Gastrointest Liver Physiol. 2005; 288: G849-G853.

22. Rhoades RA. and Bell DR. Medical physiology- $4^{\text {th }}$ edition. 2013. Lippincott Williams and Wilkins, a Wolters business

23. Katzung BG. et al., Basic and clinical pharmacology. $10^{\text {th }}$ edition. 2006. McGraw-Hill,San Francisco

24. Triggle D. j. L-Type calcium channels. Current Pharmaceutical Design. 2005; 11(7).

25. Mard S.A, Veisi A, Naseri M.K.G and Mikaili P. Spasmogenic Activity of the Seed of the Terminalia Chebula Retz in Rat Small Intestine: In Vivo and In Vitro Studies. Malaysian J Med Sci. 2011; 18(3): 1826.

26. Rang HP. Dale MM. Ritter JM. Flower R.J and Henderson G. Rang and Dale's Pharmacology $-7^{\text {th }}$ edition .2012. Elsevier Limited. 